\title{
Вплив засобів масової комунікації на природні, біологічні та соціально- психологічні чинники в процесі трудової адаптації
}

\author{
Согорін А. А., Запорізький національний технічний університет
}

У сучасний час засоби масової комунікації грають значну роль у формуванні уявлення соціуму про навколишній світ та безпосередньо впливають на поведінку окремих груп у повсякденній діяльності.

Труд $є$ одним із основних видів діяльності людини в процесі життя, тому питання поведінки індивідів та груп під час трудового процесу та самого відношення до праці, починаючи з XIX століття по сучасний час, $є$ об'єктом уваги багатьох вітчизняних та іноземних дослідників. Важливими віхами в сучасній соціології праці $є$ роботи М. П. Лукашевича, А. С. Лобанової, Г. В. Дворецької.

Одним із питань процесу трудової діяльності $є$ процес адаптації індивідів та гру до нових умов праці, а також детермінанти відповідних адаптаційних процесів.

У статті досліджено різноманітні прояви впливів засобів масової комунікації на природні, біологічні та соціально-психологічні чинники в процесі трудової адаптації.

3'ясовано, що вплив ЗМК на дію природних чинників може призвести до ефектів двох видів:

- викривлення уявлення суб'єктів трудової адаптації про реальні впливи природних (космічних) сил на умови трудової діяльності за певною професією,

- неадекватне уявлення суб'єктами трудової адаптації власних можливостей у взаємодії з природними умовами трудової діяльності. Підтверджено гіпотезу про вплив ЗМК на чинники, що зумовлюють адаптаційні процеси.

Ключові слова: трудова адаптація; масова комунікація; трудова діяльність; вплив засобів масової комунікації; ефекти засобів масової комунікації

\section{Influence of mass media on natural, biologic and social-psychological factors in process of labor adaptation}

\section{Sogorin A. A., Zaporizhzhya national technical university}

In modern time of mean of mass communication play a considerable role in forming of presentation of социума аbout outward things and directly influence on behavior of separate groups in everyday activity.

Labour is one of basic types of activity of man in the process of life, that is why question of behavior of individuals and groups during a labour process and attitude toward labour, beginning from XIX centuries for modern time, is the object of attention of many home and foreign researchers. One of questions of process of labour activity I am process of adaptation of individuals and game to the new terms of labour, and also determinant of corresponding adaptation processes.

In the article the various displays of influences of facilities of mass communication are investigational on natural one, biological and социальнопсихологические factors in the process of labour adaptation. Mass media can influence the action of «social selection», elimination from society, from the sphere of professional activity of some individuals and help to survive others. It is common knowledge that mass media can not only «create a hero», his image, but also «destroy» him in the perception of the public.

It is found out that influence of mass media on the action of natural factors can result in the effects of two kinds :

- curvature of presentation of subjects to labour adaptation about the real influences of natural (space) forces on the terms of labour activity after a certain profession

- inadequate presentation by the subjects of labour adaptation of own possibilities in co-operating with the natural terms of labour activity. A hypothesis is confirmed about influence of mass media on factors which predetermine adaptation processes.

The means of mass communication affect practically all the basic biological stimuli, which determine the adaptive behavior of a person: the instincts of hunger, self-preservation, the continuation of the genus, movement, and others.

- Mass media has a significant role in destroying the mechanisms of biological instincts, which has led to an increase in the impact on the adaptive behavior of human socio-psychological factors.

- Interacting with other socio-psychological stimuli, mass media can not but change the influence of these stimuli on the adaptive behavior of man.

Keywords: labor adaptation; mass media; labor activity; mass media influence; mass media effects 


\title{
Влияние средств массовой коммуникации на природные, биологические и социально-психологические факторы в процессе трудовой адаптации
}

\author{
Согорин А. А., Запорожский национальный технический университет
}

В современное время средства массовой коммуникации играют значительную роль в формировании представления социума об окружающем мире и непосредственно влияют на поведение отдельных групп в повседневной деятельности.

Труд является одним из основных видов деятельности человека в процессе жизни, потому вопрос поведения индивидов и групп во время трудового процесса и самого отношения к труду, начиная с XIX века по современное время, является объектом внимания многих отечественных и иностранных исследователей. Важными вехами в современной социологии труда являются работы М. П. Лукашевича, А.С. Лобановой, Г.В. Дворецкой.

Одним из вопросов процесса трудовой деятельности есть процесс адаптации индивидов и игру к новым условиям труда, а также детерминанты соответствующих адаптационных процессов.

В статье исследованы разнообразные проявления влияний средств массовой коммуникации на естественные, биологические и социальнопсихологические факторы в процессе трудовой адаптации.

Выяснено, что влияние СМК на действие естественных факторов могут привести к эффектам двух видов:

- искривление представления субъектов трудовой адаптации о реальных влияниях естественных (космических) сил на условия трудовой деятельности за определенной профессией

неадекватное представление субъектами трудовой адаптации собственных возможностей во взаимодействии с естественными условиями трудовой деятельности. Подтверждена гипотеза о влиянии СМК на факторы, которые предопределяют адаптационные процессы.

Ключевые слова: трудовая адаптация; массовая коммуникация; трудовая деятельность; влияние средств массовой коммуникации; эффекты средств массовой коммуникации

\section{Постановка проблеми.}

\ країнське суспільство продовжує багатолітній перехід до ринкових відносин за умови глибокої соціальної кризи, що ускладнює адаптацію до них населення, тому найважливішою метою $є$ пошук ефективних соціальних механізмів адаптації та соціалізації до нових умов праці. В той же час ЗМК, які дійшли бурхливого розвитку у XXI столітті, $є$ одним із найвпливовіших механізмів адаптації та соціалізації і не в повній мірі виконують свою соціальну роль, а дослідження впливу ЗМК на трудову адаптацію має суперечливий характер. Однією 3 причин такої ситуації - недостатньо чітке розуміння соціологами сутності впливу ЗМК на трудову адаптацію в сучасній Україні.

Усе вищевказане визначає теоретичну й практичну актуальність теми дослідження.

Аналіз публікацій і досліджень.

Загальні питання дослідження засобів масової комунікації досліджували П. Віріліо, С. Холл, Дж. Фіске, У. Еко та ін. Роль засобів масової інформації в перехідний період як один 3 джерел інформаційного відшкодування розглядається в працях по інформаціологіi (Прігожин І., Стенгерс I., Курдюмов С. П., Степін В. С, Юзвішин I. І., Проніна Л. А., Поелуева Л. А., Горелик О. М., Князєва О. Н. та ін.). Проблемам впливу візуальних образів на масову свідомість в ЗМІ приділили значну місце в своїх дослідженнях Е. Дюркгейм, М. Вебер, Г. Зіммель, І. Гофман, П. Бурдьє, Дж. Баргер, Г. Поллок, Ж. Бодрийяр, 3. Бауман, Х. Ортега-і-Гассет, П. Валері, М. Межуєв, Е. Доценко, Л. Набокова, А. Ганіс і ін. Проблема адаптації вперше була висунута і науково обгрунтована видатними біологами Ж. Б. Ламарка, Ч. Дарвіна,
Ж. Сент-Ілером, які розуміли іï в контексті концепції еволюції.

Основна частина публікацій присвячена дослідженням окремих видів адаптації або є наслідком вирішення практичних проблем. Найбільш частим предметом дослідження виступають: соціально-психологічна адаптація (М.П.Будякіна, І.А.Георгієва, Т.Г.Дічєв, О.І.Зотова, М.Л.Іванов, Р.У.Ісмагілов, І.К .Кряжева, Р.А.Кузьміна, А.А.Налчаджян, Ю.Л.Неймер, В.М.Пономаренко, Л.Г.Пріпутень, А.А.Русалінова, А.Л.Свенціцбкий, С.Абдель Хаді) ; виробнича адаптація (В.Ф.Галигін, С.М.Дмітренко, Б.П.Кутирьов, А.А.Хван); професійна адаптація (Р.Колосова, В.Немченко, Н.В.Полякова) адаптація молодих фахівців або працівників (С.Д.Артемов, В.Н.Безносіков, 3.Н.Камишев, Т.Л.Кончанін, А.Лукьянов, Н.Б.Отраднова, А.І.Ходаков). У цих дослідженнях і розглядаються основні теоретичні проблеми адаптації до трудової діяльності.

Однак, незважаючи на значний бібліографічний матеріал щодо вивчення засобів масової комунікації та трудової адаптації питанню впливу засобів масової комунікації на природні, біологічні та соціально-психологічні чинники в процесі трудової адаптації не приділено значної уваги в науковому дискурсі.

Мета дослідження - аналіз ефектів масової комунікації щодо біологічних, природних та соціально-психологічних чинників поведінки людини, а також підтвердження гіпотези про вплив цих чинників на трудову адаптацію.

Виклад основного матеріалу.

Засоби масової комунікації можуть впливати на дію природних чинників поведінки через участь у створенні картини світу природи або уяви 
про дію тих чи інших природних сил на людину. При цьому перебільшення можливостей людини у взаємодії з силами природи на екрані телевізора може призвести до неадекватних дій глядача в реальному житті. Особливо небезпечна така неадекватність оцінки наслідків взаємодії у дітей, які не завжди в змозі розрізнити ці дії в реальному та віртуальному світах (недооцінка небезпек, пов'язаних із користуванням сірниками та іншими вогненебезпечними речами, недооцінка загроз для здоров'я і життя від користування зброєю або наслідування трюків героїв телесеріалів тощо).

Небезпечними можуть бути i перебільшення дії сил природи на людську поведінку. Вони можуть не тільки викликати страх перед силами природи, відчуття власної безпорадності й неспроможності управляти власною поведінкою. Нерідко фільми жахів, катастроф і містичні трилери сприяють відхиленню у психіці людини. У цьому випадку ЗМК підсилюють залежність від природних чинників, зменшуючи поле для дії біологічних та соціально-психологічних факторів.

Отже, вплив ЗМК на дію природних чинників поведінки людини може призвести до ефектів двох видів:

1. Викривлення уявлення суб'єктів трудової адаптації про реальні впливи природних (космічних) сил на умови трудової діяльності за певною професією.

2. Неадекватне уявлення суб'єктами трудової адаптації власних можливостей у взаємодії 3 природними умовами трудової діяльності.

Переходячи до розгляду впливів комунікації на дію біологічних чинників поведінки людини, нагадаймо, що до останніх зараховують такі: основні біологічні потреби, флора і фауна, спадкоємність, звички та умовні рефлекси. Біо ᄀлогічні сили є не тільки рушійними механізмами дій людини, але й «були i залишаються головними пружинами суспільних рухів» [2, с. 90-132]. Розглянемо коротко прояви ефектів впливу масової комунікації на дію цих основних біологічних сил у процесі трудової адаптації.

Загальними характеристиками біологічних (життєзберігаючих) потреб є їх призначення зберігати життя організму людини. Вони отримуються разом з організмом через спадкоємність, не залежать від свідомості й особистісного досвіду, притаманні всім живим організмам. Їх ще називають рефлексами й інстинктами. Незадоволення будь-якої біологічної потреби наполегливо вимагає певної дії людини щодо іiі задоволення, виступаючи могутнім чинником поведінки людини.

Головними біологічними потребами є такі: потреби в їжі, потреба статева (розмноження, потреба індивідуального самозахисту, потреба групового самозахисту, несвідоме наслідування, потреба в русі, потреба сну і спокою, витрат додаткової енергії (гра) тощо.

Потреба в їжі є найсильнішим подразником дій людини, вона впливає на хід думок і уявлень, витісняючи ті з них, що не мають стосунку до їжі. Отже так само сильним є і зворотний зв'язок. Думки й уявлення про їжу, навіяні передачами 3МК, можуть штучно актуалізувати потребу в іжі; обмежити сприйняття людиною інших явищ і пред-

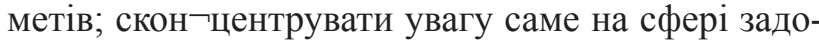
волення цієї потреби; сприяти підвищеній купівлі продуктів харчування та їх завищеному споживанню. При цьому під впливом ЗМК завищена потреба в їжі може викликати ослаблення чи подолання інших біологічних потреб (самозахисту, розмноження) та деяких суспільно-психологічних подразників (релігійних, правових і моральних чинників). Крім того, під впливом реклами чи моди можуть викривлятись і руйнуватись інстинктивні механізми харчування. Часто на цій підставі виникає надмірне вживання їжі, порушення режиму харчування. Звичайно, ЗМК можуть сприяти (i в певній мірі сприяють) поширенню знань про науково обгрунтовані форми задоволення потреби в їжі, які можуть частково компенсувати руйнацію інстинктивного механізму. Але вплив такого ефекту МК на населення вкрай обмежений. Отже, «спровокована» ЗМК підвищена потреба в їжі в суб'єкта трудової адаптації може послабити (і навіть витіснити) іншу мотивацію вибору місця роботи та адаптації на ньому.

Подібно до потреби харчуватись, інстинкт продовження роду дається людині разом з організмом, а його вплив на поведінку людини також $\epsilon$ одним із найсильніших. Відповідно, значною $\epsilon$ можливість впливати через ЗМК на окремі сторони поведінки людини, підсилюючи або послаблюючи дію цієї потреби.

На фізіологічному рівні під впливом еротичних, сексуальних або навіть порнографічних сцен 3 екрана ТБ або Інтернету у глядачів може виникнути підвищена активність, а подеколи й напруга відтворювальної системи в ор-ганізмі, що, у свою чергу, позначатиметься на рухах, вчинках, зовнішньому вигляді людини.

На рівні уявлень та ідей подібні передачі можуть вплинути на нормальне функціонування психіки через витіснення всіх уявлень і думок, що не стосуються цієї потреби. Світ уявлень людини заповнюється сексуальними образами та думками, їй важко сконцентруватись на чомусь іншому. Подібні ефекти мас-медіа можуть мати небезпечний характер для молодих людей, в яких ця потреба актуалізована в силу вікових фізіологічних змін в організмі. За певних обставин їх поведінка може набути ознак не тільки сексуальної нервозності, але й сексуальної агресії.

На рівні сприйняття ефекти мас-медіа можуть проявитись у підвищеній увазі та чутливості до предметів і явищ, що мають стосунок до статевої потреби та в послабленні уваги до всього іншого. Саме вплив такого ефекту використовують 3МК у рекламі, коли широкий асортимент професій, 
товарів, призначених для задоволення зовсім не статевої потреби, подається в поєднанні або на фоні сексуальних і еротичних образів, штучно паразитуючи при цьому на переключенні і концентрації уваги навколо задоволення статевої потреби. Подібне переключення не сприяє адекватній оцінці робіт, послуг і товарів, що пропонуються в рекламі. Зрозуміло, що ЗМК відіграють також позитивну роль щодо статевого виховання підростаючого покоління. Важко переоцінити їх роль у здійсненні сексуальної революції, яка суттєво демократизувала гендерні відносини у світі.

Водночас ЗМК не вдається ефективно диференціювати свої впливи за віковими та етнічними ознаками, що подеколи призводить до неконтрольованих і непередбачуваних наслідків. За певних обставин під впливом передач сексуального спрямування потяги до задоволення статевої потреби долають інстинкт самозбереження, релігійні й морально правові заборони та норми, переваги тієї чи іншої професії.

Наприкінці зазначимо, що описані вище «двигуни людської поведінки» - інстинкти задоволення потреб в їжі та продовженні роду якщо не прямо, то опосередковано сприяють збереженню та підтримці життя людини, іiі життєдіяльності у всіх сферах, зокрема в трудовій. У той же час існує інстинкт самозбереження у вужчому розумінні. Його роль полягає в тому, щоб спонукати людину на такі дії, що унеможливлюють небезпеку, яка безпосередньо загрожує життю організму. Він проявляється у двох формах:

1. інстинкт індивідуального самозбереження;

2. інстинкт групового (родового) самозбереження.

Інстинкт індивідуального самозбереження виступає у двох формах: у формі чисто біологічного інстинкту (у вигляді несвідомих актів) та у формі інстинкту усвідомленого (завуальованого міркуваннями користі, задоволення та інше).

Проявами чисто біологічного інстинкту самозбереження $є$ всі несвідомі акти поведінки людини, спрямовані на усунення опосередкованої чи безпосередньої небезпеки для життя будь-якого характеру - космічного, біологічного або соціально-психологічного. Сигналами попередження загроз здоров'ю організму слугують біль і страждання. Отже, механізм самозбереження спрямований на уникнення джерел болю та страждання.

Зазначимо, що під впливом соціально-психологічних подразників у сучасної людини доцільно-природний механізм цього інстинкту переважно зруйнований і розбалансований. ЗМК у такому руйнуванні беруть активну участь шляхом викривлення «простору небезпеки», дезорієнтації щодо сили і спрямованості небезпечних чинників.

Жах і відчуття загрози, що виникає під впливом ЗМК на рівні підсвідомості індивіда, не тільки позначаються на ході фізіологічних процесів (порушення ритму серцебиття, дихання, трав- лення, потовиділення тощо), але й призводить до неадекватних реакцій на «нормальні» сигнали від навколишнього середовища, виникнення стану пригніченості, роздратованості, агресивності та ін., що можуть проявлятись також в адаптивній поведінці.

Однак, найчастіше інстинкт самозбереження у людей проявляється в усвідомленій формі. При цьому небезпека усвідомлюється людиною, яка під контролем розуму здійснює ряд актів, спрямованих на свій порятунок. Джерелом інформації про загрози і небезпеки нерідко виступають ЗМК. Під впливом насильства, жорстокості, кривавих кримінальних «розборок», фільмів жахів i катастроф, містичних трилерів 3 поля свідомості витісняються всі «зайві» думки й уявлення. Воно заповнюється жахом і небезпекою, усе концентрується навколо однієї думки - «як врятуватись?», «як зберегти життя?».

За таких обставин під дією віртуальних сигналів щодо загрози життю здійснюється «запуск» як усвідомлених, так і не усвідомлених інстинктивних механізмів самозбереження, які можуть «перекрити» вплив інших інстинктів поведінки людини - голоду, статевого тощо. Нерідко можуть бути «перекриті» впли $\neg и$ на поведінку людини релігійного та морально-правових подразників, переваг тієї чи іншої трудової діяльності, певного місця роботи.

Зазначимо, що на впливі інстинкту самозбереження засновано такий метод управління поведінкою людей, як терор. ЗМК досить часто залучаються для ретрансляції вимог терористів, розширення простору впливу терору.

Звичайно, не варто перебільшувати впливи ЗМК на руйнування і викривлення механізму інстинкту самозбереження, адже останній не є єдиним «мотором» людської поведінки, а тільки одним із чинників, дія якого залежить не лише від його власної сили, але й від сили та напрямів дії інших «моторів». Одним із таких моторів $\epsilon$ інстинкт групового самозбереження.

Якщо описаний вище інстинкт індивідуального самозбереження спрямований на збереження життя індивіда, то інстинкт групового самозбереження спрямований на збереження життя всієї групи. Виникнення цього інстинкту обумовлено необхідністю об'єднання зусиль окремих людей для виживання в небезпечному природному й соціальному середовищі. Для розвитку життя важливо було зберегти не тільки (і не стільки) індивіда, але й цілий рід або вид. У цьому випадку інстинкт групового самозбереження проявляється у вигляді «суспільності»- життя групами, спільнотами, в яких безпека життя кожного «свого» обумовлена мірою групової безпеки, що «фіксується» домінуванням інстинкту групового самозбереження.

Залежно від того, кого зараховують до категорії «своїх», у різних людей інстинкт групового 
самозбереження, що проявляється у домінуванні його над інстинктом індивідуального самозбе- реження, готовності жертвувати собою заради «ближніх», виглядає по-різному (див. табл. 1).

Таблиця 1

Прояви інстинкту групового самозбереження в різних спільнотах

\begin{tabular}{|l|l|}
\hline \multicolumn{1}{|c|}{ Визнані ближніми } & \multicolumn{1}{|c|}{ Спрямованість самопожертви } \\
\hline Родичі & Заради сім’ї \\
\hline Члени територіальних спільнот & Заради земляків \\
\hline Члени національних спільнот & Заради нації (народу) \\
\hline Члени партії чи класу & Заради партії чи класу \\
\hline Члени країни, держави & Заради батьківщини, держави \\
\hline Усі люди світу & Заради людства \\
\hline
\end{tabular}

Як бачимо, інстинкт індивідуального самозбереження набуває різних форм самопожертви індивідів на користь тієї чи іншої групи. А у визначенні цих груп у громадянській свідомості, побудові ієрархії їх важливості для конкретного суспільства суттєву роль відіграють ЗМК.

По-перше, вплив ЗМК може проявитись у визначенні і нав'язуванні індивідам уявлень і сте-

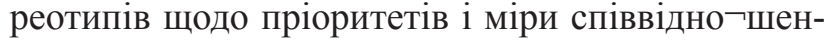
ня індивідуальних і групових інстинктів самозбереження

По-друге, це вплив щодо визначення і нав'язування певних рейтингів, значущості інстинктів групового самозбереження тих чи інших груп i спільнот. Це надає ЗМК можливості маніпулювати свідомістю людей щодо їх індивідуальної та групової безпеки, механізмів самозбереження.

По-третє, спрямованість самопожертви заради сім’ї під впливом ЗМК може стати домінуючим мотивом вибору адаптації на певному місці роботи.

Ще однією формою прояву інстинкту групового самозбереження $є$ так званий «батьківський інстинкт». Він проявляється в любові до дітей, турботі про них, допомозі в забезпеченні їх життєдіяльності, захисті від небезпеки й загроз, і навіть нерідко готовності до самопожертви заради збереження життя і здоров'я дітей. Нерідко цей інстинкт проявляється в людей у несвідомій формі, але частіше за все в усвідомленому вигляді. Саме на рівень і характер його усвідомлення впливають суспільно-психологічні чинники, зокрема ЗМК. Пропаганда в суспільстві сімейних цінностей підтримує усвідомлення цього інстинкту, водночас домінування прагматичних цінностей, орієнтація на індивідуалістичні засади побудови суспільства сприяють послабленню та руйнуванню такого важливого механізму самозбереження спільнот i суспільства в цілому. Особливо небезпечний руйнівний вплив у традиційних суспільствах, де сімейні цінності $€$ основою національного менталітету. У таких суспільствах, зокрема в Україні, традиційна модель поведінки батьків («усе заради дітей»), яка передбачає супровід, тобто допомогу дітям у доланні труднощів трудової адаптації, певний тиск на дітей щодо вибору «престижного» (на думку батьків) місця роботи, де можливості батьків щодо допомоги є найбільшими. У ринкових умовах ця традиція вступає в протиріччя 3 необхідністю заповнювати робочі місця професіоналами, а також з розширенням вимог вибору професії і місця роботи з боку дітей. Отже, отримання від ЗМК правдивої, соціально-обгрунтованої інформації щодо професій і стану ринку праці надалі ускладнюється.

Ще одним важливим для розуміння впливів ЗМК на індивіда видом інстинктів $є$ несвідоме наслідування дій інших людей - сміх, позіхання, жах та ін. Крім того, під впливом несвідомого наслідування та навіювання у людей виникають шаблони смаків та оцінок, які впливають на поведінку.

Впливи ЗМК обумовлені їх участю у створенні особливих сприятливих умов для прояву несвідомого наслідування, обставин, що призводять до приспання та оглушення вищих центрів свідомості, ослаблення й припинення контролю з боку індивіда за подразниками і своїми відповідними реакціями у вигляді актів і дій. 3 одного боку, цьому сприяють бідність та монотонність вражень, які послаблюють діяльність вищих форм нашої розумової діяльності, особливо у дітей і осіб 3 недостатньо розвиненим розумом. Думається, що саме на таких засадах здійснюється маніпулювання свідомістю й поведінкою людей у тоталітарних суспільствах. Водночас, прояви ефектів ЗМК у сучасних демократичних суспільствах мають дещо іншу основу, яка призводить, як не дивно, до аналогічних результатів.

Оглушення свідомості, ii притуплення відбувається і тоді, коли на людину впливає занадто багато подразників. Свідомість не встигає справитися 3 ними i «переварити» їх, відбувається ослаблення роботи вищих форм свідомості і перетворення людини на пасивний автомат, що неусвідомлено підкорюється навіюванню. Як бачи- 
мо, вплив ЗМК на оцінку трудової ситуації дітьми, молоддю та людьми недостатньо освіченими та незвиклими до розумової діяльності, може призвести до значних змін у стереотипних оцінках і поведінці, а за певних обставин - до почуття залежності від такого отупляючого свідомість впливу. Крім того, можливим є і зворотний зв'язок - під впливом ЗМК може зменшуватись потреба в усвідомленій розумовій діяльності, у зваженій оцінці і власному аналізі подій і фактів, адаптивних ситуацій у трудовій сфері. Зручні до вжитку готові стереотипи і моделі поведінки, що пропонують ЗМК, спонукають усе частіше звертатись до них за «порадою» все ширшої аудиторії. Додаткові можливості для впливів ЗМК на поведінку людей створює наявність у них біологічної потреби рухатись. Звичайно, ця потреба може реалізуватись ЗМК не через створення реальних умов для іiі задоволення, а в пропозиції віртуального простору, наповненого динамічними подіями, рухами, спортивними змаганнями, іграми, в яких герої долають складні перешкоди, витрачаючи на це значні фізичні зусилля, демонструючи динамічне, рухливе життя.

Ототожнюючи себе 3 героями, «перебираючи», «приміряючи» на себе їх динамізм і рухливість, глядачі телепередач (особливо діти), сидячи годинами перед телеекраном, потерпають від нестачі руху в їх житті, а нерідко й від гіподинамії. Від подібних впливів страждають юні користувачі комп'ютерних ігор, а при неврегульованому споживанні такої послуги навіть стають залежними. Прикро, що в комп'ютерних іграх практично не використовуються сюжети професійного спрямування, на яких могли б відпрацьовуватись моделі адаптивної поведінки щодо засвоєння тієї чи іншої професії.

Підсумуємо аналіз проявів ефектів масової комунікації на дію біологічних чинників щодо поведінки людини такими узагальненнями:

1. ЗМК впливають практично на всі головні біологічні подразники, що обумовлюють адаптивну поведінку людини: інстинкти голоду, самозбереження, продовження роду, руху та інше.

2. ЗМК належить суттєва роль у руйнуванні механізмів біологічних інстинктів, що привело до збільшення впливів на адаптивну поведінку людини соціально-психологічних чинників.

3. Взаємодіючи 3 іншими соціально-психологічними подразниками, ЗМК не можуть не змінювати вплив цих подразників на адаптивну поведінку людини.

Переходячи до розгляду впливів ЗМК на соціально-психічні подразники, нагадаймо, що до цих подразників зараховують прості (ідеї, почуття-емоції та воління) та складні, які об'єднують декілька простих соціально-психічних подразників, космічні й біологічні подразники (часто вони розглядаються як інтегрований подразник соціальне середовище).
На відміну від впливів на поведінку космічних i біологічних подразників, залежність від яких суттєво сприймається людиною як обмеження (і навіть відсутність) свободи, залежність від соціально-психічних подразників сприймається нами як «вільна», така, що не обмежує нашої свободи. Адже діяти у відповідності з нашими ідеями (знаннями і віруваннями), почуттями і воліннями (а саме вони $є$ головними соціально-психічними подразниками) означає для нас діяти вільно, без обмежень нашої свободи. Таким чином, зростання впливів соціально-психологічних подразників сприйматиметься нами як зростання власної свободи, що практично унеможливлює відчуття або усвідомлення можливих маніпуляційних впливів на аудиторію.

Крім того, ЗМК, взаємодіючи 3 іншими соціально-психологічними подразниками (ідеями, почуттями-емоціями, бажаннями), можуть підсилювати або послаблювати «звільняючі» прояви ефектів їх впливу на поведінку людини.

Переходячи до розгляду впливів ЗМК на ідеї як чинник адаптивної поведінки варто уточнити, як саме ідеї обумовлюють поведінку людини.

Як відомо, ідеї існують у кожної людини як результат задоволення сутнісної потреби - мислення. У процесі мислення людина за допомогою ідей пояснює, обгрунтовує, мотивує своє бачення світу і свою поведінку. Якщо ідеї мають характер знань, тобто відображають об'єктивний зв'язок між предметами та явищами, то їх вплив на поведінку $\epsilon$ обгрунтовано виваженим і раціональним. Коли ж ідеї мають вигляд вірувань, то й уявлення людей про навколишній світ буде хибним, а, відповідно, пояснення та мотивація власної поведінки не відповідатимуть об'єктивно існуючим природним і суспільним зв'язкам. Але суб'єктивно і «людина знаюча», і «людина віруюча» переконані в істинності своїх ідей і з однаковою впевненістю керуються ними в обгрунтуванні своїх уявлень та теорій, поясненні своєї поведінки. Хоча ідеї-знання носять об'єктивний характер, розкривають суть речей і за ними не стоять суб'єктивні інтереси окремих людей, груп і організацій. А ідеї-вірування не є об'єктивними, вони відображають інтереси тих людей, які замість викладання того, що дійсно $є$, тобто знань, істинних для всіх, декларують і відстоюють своє суб' єктивне бачення, яке не може не відображати їхні власні інтереси. Звідси зрозуміло, чому люди різних груп і класів керуються різними ідеями-віруваннями й чому їм так важко порозумітися.

Зрозумілими також стають величезні можливості ЗМК, у матеріалах яких відбувається продукування ідей як у вигляді знань, так і у вигляді вірувань. Поширюючи і відображаючи у свідомості людей знання 3 широкого спектра природних і суспільних ідей, ЗМК озброюють людей об'єктивним матеріалом для мислення, для нау- 
кового пояснення явищ навколишнього світу, розуміння механізмів власної адаптивної поведінки й обгрунтованої іiі мотивації.

3 іншого боку, нерідко ЗМК у гонитві за сенсацією та прибутком транслюють ідеї-вірування, надаючи їм «науково-образного» характеру. Так, переважно на хибних, неперевірених ідеях базується реклама в ЗМК. Звичайно, що людям 3 невисоким рівнем знань, схильних до орієнтації на вірування, подібна рекламна продукція щодо професії і ринку праці здається правильною. До того ж слабке володіння науковим мисленням не дає їм змоги критично оцінити істинний характер реклами. За таких обставин хибні ідеї щодо престижу та характеристик професії сприймаються людиною як iii вільний вибір, а діяльність щодо їх реалізації - як набуття нею свободи в професійному самовизначенні. Отже, виникають сприятливі умови для маніпулювання свідомістю й поведінкою людини в трудовій сфері, що ускладнює іiі трудову адаптацію.

Разом із тим ЗМК мають значні можливості посилення або ослаблення впливів ідей на адаптивну поведінку людини опосередковано, за допомогою почуттів-емоцій.

Це особливий вид психічних переживань, що супроводжуються задоволенням i стражданням та грунтуються на біологічних механізмах людини прагнути задоволення-насолоди й уникати болю-страждань.

Почуття-емоції є ускладненими проявами біологічних імпульсів і інстинктів, які через ускладнення психічного життя людини відокремились від чисто біологічних імпульсів і набули «усвідомленого» вигляду, тобто мають розглядатись разом iз соціально-психологічними подразниками [2, с. 155-156]. Водночас саме близькість до біологічних подразників надає почуттям-емоціям особливої сили впливу на поведінку людини й особливі можливості для ЗМК використовувати почуття-емоції для впливу на адаптивну поведінку людей, який здійснюється як безпосередньо, так і опосередковано. Безпосередній вплив здійснюється через створення за допомогою різних форм мистецтва (жанрів) ситуацій, образів, картин, що виникають у глядача (слухача), аудиторії очікуваних почуттів-емоцій у вигляді переживань любові чи ненависті, симпатії чи гніву, поваги чи відрази, страху й таке інше. Через близькість до біологічних подразників почуття-емоції слабко контролюються свідомістю і тому можуть стати рушійною силою вчинків і дій, не притаманних цій людині й неможливих у емоційно спокійній ситуації. Отже, ЗМК мають можливість впливати на адаптивну поведінку людини поза їі власним контролем.

Окрім того, безпосередній вплив пов'язаний 3 такою особливістю почуттів-емоцій, як здатність передаватись від людини до людини, «навіювати» ïx, тим самим обумовлюючи характер їхньої взаємодії. У результаті почуття ненависті до певної людини або групи людей може викликати таку ж ненависть і можливі агресивні дії у людини, яка дивиться програму за тисячі кілометрів від студії. А почуття відрази до кіногероя певної професії може викликати відразу до цієї професії в реальному житті.

Суть опосередкованого впливу ЗМК через почуття-емоції полягає у використанні їх для посилення або ослаблення інших груп подразників - космічних, біологічних і соціально-психологічних. Так, почуття любові може долати загрозу від стихійного лиха у людини, яка рятує предмет своєї любові. Почуття ненависті може пересилювати інстинкт голоду чи продовження роду. Ідея, забарвлена емоційним піднесенням актора, стає переконливою і впли $\neg$ вовою. Ці приклади, кількість яких постійно зростає, доводять, що почуття-емоції $\epsilon$ чи не найважливішою силою, використовуючи яку ЗМК отримують змогу впливати на адаптивну поведінку людини в цілому або на окремі їі складові. А здатність емоцій передаватись від людини до людини обумовлює можливість ЗМК впливати не тільки на окремих людей або групи на мікрорівні, але й на масову аудиторію, чисельні спільноти, народи й суспільство в цілому (на макрорівні).

Ще одним важливим видом психічних переживань людини, що надає ЗМК можливість впливати на поведінку людини, є бажання - активне намагання досягти певної мети, доклавши до цього вольових переживань і актів (дій). Зазвичай люди проявляють свої бажання словами «я хочу», «я повинен», «я не хочу», «я не повинен». У формі моральних (рекомендованих) і правових (обов' язкових) бажань (волінь) вони впливають на поведінку як мотиваційна сила, дресируюча і як сила, що здійснює соціальний відбір. У кожному 3 варіантів вини можуть як підсилюватись, так і послаблюватись ЗМК.

Так, трансляція на масову аудиторію творів, у яких досягнення успіху героїв здійснюється не трудовою діяльністю, а за допомогою неправових чи аморальних дій тим самим послаблює або руйнує моральні обмеження бажань, вони можуть мати асоціальний характер. Отже, здійснюється зміна в мотивації трудової (і адаптивної) поведінки індивіда.

3 іншого боку, чітка пропаганда правових норм, роз'яснення дій, підтвердження дієвості закону в передачах можуть суттєво застерегти людину від бажань і дій кримінального характеру щодо набуття матеріальних і моральних переваг. Таким чином, підкреслюється дресируюча роль бажань щодо формування моделі адаптивної поведінки, що визначається суспільством.

Нарешті, ЗМК можуть впливати на дію «соціального відбору», усунення із суспільства, зі сфери професійної діяльності одних осіб і допомога виживанню інших. Загальновідомо, що ЗМК можуть не тільки «створити героя», його 
імідж, але й «знищити» його в сприйнятті громадськості.

Наприкінці зазначимо, що розглянуті прояви впливів ЗМК на адаптивну поведінку людини стосувались їх дії на прості подразники - космічні, біологічні та соціально-психологічні. Вони доводять, що впливи ЗМК охоплюють практично всі ці подразники. Водночас у реальному житті подразники мають складний характер, вони об'єднують різні конфігурації простих подразників, що дає підстави визнати впливи ЗМК практично на всі подразники, a, значить, i на всі види адаптивної поведінки як окремої людини, так і груп, спільнот, суспільств.

\section{Висновки.}

1. Вплив ЗМК на дію природних чинників може призвести до ефектів двох видів:

- Викривлення уявлення суб'єктів трудової адаптації про реальні впливи природних (косміч- них) сил на умови трудової діяльності за певною професією.

- Неадекватне уявлення суб'єктами трудової адаптації власних можливостей у взаємодії $з$ природними умовами трудової діяльності.

2. ЗМК впливають практично на всі головні біологічні подразники, що обумовлюють адаптивну поведінку людини: інстинкти голоду, самозбереження, продовження роду, руху та інше.

3. ЗМК належить суттєва роль у руйнуванні механізмів біологічних інстинктів, що призвело до збільшення впливів на адаптивну поведінку людини соціально-психологічних чинників.

4. Взаємодіючи 3 іншими соціально-психологічними подразниками, ЗМК не можуть не змінювати вплив цих подразників на адаптивну поведінку людини.

\section{БІБІЛІОГРАФІЧНІ ПОСИЛАННЯ}

1. Лукашевич М. П. Соціалізація. Виховні механізми і технології: Навч.-метод. посібник / М. П. Лукашевич. Київ: ІЗМН, 1998. - 112 с.

2. Сорокин П. А. Общедоступный учебник социологии. Статьи разных лет / П. А. Сорокин. - М.: Наука, 1994. - 560 с.

\section{REFERENCES}

1. Lukashevy'ch, M. (1998) Socializaciya. Vy’xovni mexanizmy'i texnologiyi: Navch.-metod. posibny'k [Socialization. Educational mechanisms and technologies]. Kyiv [in Ukrainian].

2. Sorokin, P. (1994) Obschedostupnyiy uchebnik sotsiologii. Stati raznyih let [Public sociology textbook. Articles from different years]. Moscow [in Russian].

\section{Согорін Андрій Анатолійович}

Кандидат соціологічних наук, доцент

Класичний приватний університет

69000, м. Запоріжжя, вул. Жуковського, 70-Б

\section{Sogorin Andriy}

$\mathrm{PhD}$ in sociology, associate professor

Zaporizhzhya national technical university

64, Zhukovs'ky’j Str., Zaporizhzhya, 69000

ORCID: 0000-0003-1180-260X_Ｅmail: sogorin@i.ua

Цитування: Согорін А. А. Вплив засобів масової комунікації на природні, біологічні та соціально-психологічні чинники в процесі трудової адаптації / А. А. Согорін // Науково-теоретичний альманах «Грані». - 2018. - T. 21. - № 3. - С. 33-40

Citation: Sogorin, A.A. (2018). Vplyv zasobiv masovoi komunikatsii na pryrodni, biolohichni ta sotsialnopsykholohichni chynnyky v protsesi trudovoi adaptatsii [Influence of mass media on natural, biologic and social-psychological factors in process of labor adaptation]. Scientific and theoretical almanac "Grani», 21(3), $33-40$. 